\title{
Effect of Cement and Compaction on the Physicochemical Behavior of a Material in the Region of Sidi Bel Abbes
}

\author{
N. S. Ikhlef \\ Laboratory of Civil Engineering \\ and Environment \\ Djillali Liabès University \\ Sidi Bel-Abbès - 22000, Algeria \\ ikhlefsaidnour@yahoo.fr
}

\author{
M. S. Ghembaza \\ Laboratory of Civil Engineering \\ and Environment \\ Djillali Liabès University \\ Sidi Bel-Abbès - 22000, Algeria \\ sm_gou@yahoo.fr
}

\author{
M. Dadouch \\ Laboratory of Civil Engineering \\ and Environment \\ Djillali Liabès University \\ Sidi Bel-Abbès - 22000, Algeria \\ mokhtardaddouche@yahoo.fr
}

\begin{abstract}
Soil treatment describes the procedure under which a soil acquires certain characteristics that did not originally have. This paper is focused in the field of road earthworks and the treatment of a material found in the region of Sidi Bel Abbes, Algeria. This material has poor characteristics that do not meet the standards used in road geotechnics. To remedy this, firstly, the Proctor Standard characteristics of this material were improved using mechanical treatment that increased the compaction energy. Then a chemical treatment was employed, adding some cement dosages, and results show that the material classified in the $A_{1 \mathrm{~h}}$ class, for an increased maximum dry density and a reduction in water content. A comparative study is made on the optimal properties of the material between the two modes of treatment. On the other hand, after treatment, one finds a decrease in the plasticity index and the methylene blue value. This material exhibits a change of class. Therefore, soil class $C L$ turned into a soil class CL-ML (silt of low plasticity). This observation allows the material to be used as backfill or subgrade.
\end{abstract}

Keywords-treatment of soil; cement; methylene blue value; embankment; subgrade

\section{INTRODUCTION}

Using local materials of poor quality that are generally ignored in favor of good soils provides obvious economical advantages. Different mechanical or chemical methods are used in the treatment of soil compaction [1-2], pre-loading [3] and chemical treatment [4-9]. Today hydraulic binders treatment extends to an increasingly large number of soils: silt, clay, marl, sandy material, sandy-gravelly and gravelly etc... Cement appears to be a very effective stabilizer product. On the other hand, it has a high cost and requires a particular implementation. The cement stabilization develops from cementing ties between the hydration products of calcium silicate and aluminate and soil particles [10]. The addition of cement in clay soils reduces the liquid limit, plasticity index, swelling potential and increases the withdrawal limit and the shear strength $[6,11]$.
This work contributes to the treatment procedures employed to improve the physical properties of a material by adding cement. This method can be applied to fill and shape layers constituting the pavement structure in accordance with the standard/technical guide followed [12]. The processing technique is based on the formulation of mixtures at different percentages of cement and poor materials, in order to have a good quality material that is both economical and easy to implement.

\section{CHARACTERISTICS OF THE CONSIDERED MATERIALS}

The considered material was collected in a site located 50 $\mathrm{km}$ west of Sidi Bel Abbes, Algeria in a depth of about $65 \mathrm{~cm}$. Its physical and chemical properties are shown in Table 1 . The result of the grading curve shows that the material is very fine silty and sandy. According to [12-13], it is classified in the heading of fine soils rated Class $A$ with $D_{\max } \leq 50 \mathrm{~mm}$ and passing of $80 \mu \mathrm{m}>35 \%$. The subclass may be determined according to the methylene blue value: VBS equal to 1.23 which gives the subclass $A_{1}[14]$. For Atterberg limits we refer to [15]. The frequently water "wet" condition of the soil characterized by a relative sensitivity to water does not allow efficient compaction.

The treatment with cement is particularly suitable for less plastic soils, which are a priori unsuitable for lime treatments because of their low clay content. The adjustment of water status is determined by the natural water content $\left(\mathrm{w}_{\mathrm{n}}\right)$ : $0.9 \cdot \mathrm{w}_{\mathrm{OPN}} \leq \mathrm{w}_{\mathrm{n}} \leq 1.1 \cdot \mathrm{w}_{\mathrm{OPN}}$ with $\mathrm{w}_{\mathrm{n}}=18.86 \%[16]$.

From this analysis, it was considered useful to improve the characteristics of the material by a chemical treatment with cement in order to meet the requirements in terms of load capacity and deformation in pavement structures. The cement used is Portland Cement Artificial (CEM I) from the cement works of Chlef, Algeria. The physical and chemical properties of the cement are summarized in Table 2. 
TABLE I. PROPERTIES OF THE CONSIDERED MATERIAL

\begin{tabular}{|l|c|}
\hline Plasticity & 33,00 \\
$\mathrm{w}_{\mathrm{L}} \%$ & 11,97 \\
$\mathrm{I}_{\mathrm{P}} \%$ & \\
\hline Particle size analysis & 56,80 \\
$<80 \mu \mathrm{m}(\%)$ & 37,94 \\
$\mathrm{C}_{\mathrm{c}}=\mathrm{d}_{30} / \mathrm{d}_{10 .} \mathrm{d}_{60}$ & 0,84 \\
$\mathrm{C}_{\mathrm{u}}=\mathrm{d}_{60} / \mathrm{d}_{10}$ & \\
\hline Characteristics OPN & 16,40 \\
$\mathrm{w}_{\text {opn }}(\%)$ & 1,68 \\
$\gamma_{\mathrm{d}} / \gamma_{\mathrm{w}}$ & 2,55 \\
\hline Grain density $\left(\gamma_{\mathrm{s}} / \gamma_{\mathrm{w}}\right)$ & 1,23 \\
Methylene Blue Value & 25,75 \\
Specific Surface area $\left(\mathrm{cm}^{2} / \mathrm{g}\right)$ & 14,86 \\
\hline Natural water content $(\%)$ & \\
\hline Chemical properties & 38,86 \\
Silica $(\%)$ & 27,01 \\
Lime & 1,35 \\
Organic matter & 1,36 \\
Iron oxide & - \\
Alumina oxide & 52 \\
\hline CaCO & \\
\hline
\end{tabular}

TABLE II. PROPERTIES OF THE CEMENT USED

\begin{tabular}{|l|c|}
\hline Physical Characteristics & Values \\
\hline Specific Surface area $\left(\mathrm{cm}^{2} / \mathrm{g}\right)$ & 3500 \\
Consistance (\%) & 19 \\
Curing time (h, mn) & $2: 13$ \\
Warm dough expansion (mm) & 1,51 \\
\hline Chemical Characteristics & Values \\
\hline Insoluble (\%) & 0,97 \\
Loss on ignition (\%) & 5,14 \\
Free CaO (\%) & 0,70 \\
$\mathrm{SiO}_{2}$ & 20,71 \\
$\mathrm{Fe}_{2} \mathrm{O}_{3}$ & 3,47 \\
$\mathrm{CaO}^{\mathrm{MgO}}$ & 62,07 \\
$\mathrm{SO}_{3}$ & 1,12 \\
\hline
\end{tabular}

\section{EXPRIMENTAL PROCEDURE}

The processing procedure begins by drying the samples in the oven at $60^{\circ} \mathrm{C}$ for $24 \mathrm{~h}$, then the dry material is thoroughly mixed for about 15 min with different percentages of cement ( $2 \%, 3 \%$ and $4 \%$ by [17]). The mixing is done using a mixer with knives and optionally distilled water, until a homogeneous material is achieved. Atterberg limits and blue tests were performed on natural samples and treated in accordance with $[14,15]$.

\section{RESULT AND DISCUSSION}

\section{A. Effect of the cement on the liquid limit}

Atterberg limits of soil samples found in the natural state and mixed with different percentages of cement are shown in Figure 1. There is a strong limit liquidity passing $33 \%$ to $29.34 \%$ decrease. This decrease is due to the variation of water content with increasing cement content. This observation is in good agreement with the results in [6, 18-20]. Similar trends of the liquid limit have been observed by other researchers on materials treated with lime and pozzolan [9, 21], and on materials treated with fly ash [22-24].

The implication of this reduction in soil plasticity, with an increasing amount of cement is attributed to the process of exchange of cations between the soil and stabilizers [6]. Other authors $[4,25]$ explained that the cation exchange, flocculation of clay particles and reaction sintering process are the main physico-chemical mechanisms responsible for the improvement of mechanical properties of soils when treated with lime. In contrast, an increase in liquid limit when increasing the percentage of cement has been shown in [26]. We can say that this difference depends on the nature of the soil: namely an increase can occur for kaolinitic clay soils and a decrease may occur for clay montmorillonite [27].

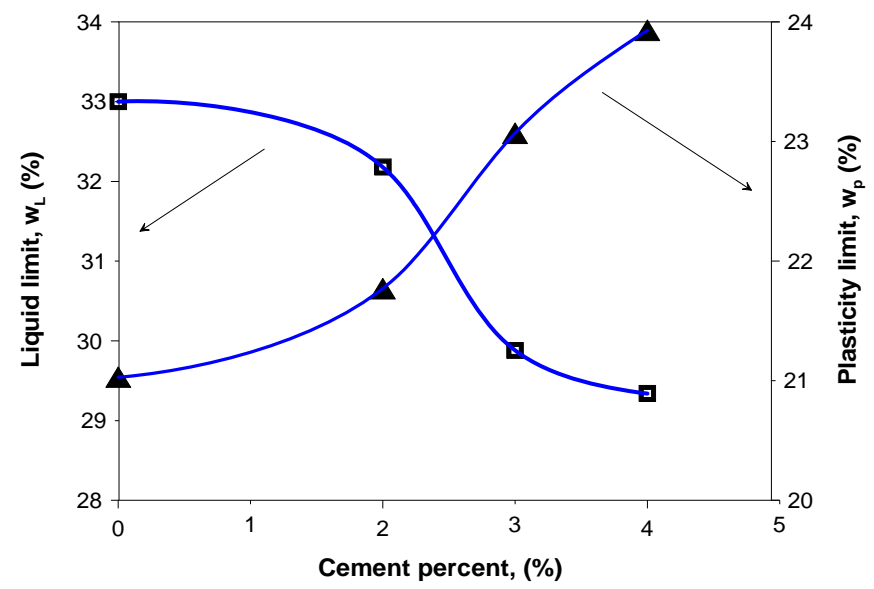

Fig. 1. Variation of the liquid limite and plasticity varius percentage of cement.

\section{B. Effect of the cement on the plastic limit}

Regarding the plastic limit wp, the treated samples showed an increase of the limit with the increase of the amount of cement (Figure 2). This limit increased from $21 \%$ to $23.93 \%$. The same trends have been observed on materials treated with lime [28] and on materials treated with limestone [5]. The same behavior was also observed in [9, 22, 29-30]. It has been shown that the addition of fly ash at low calcium soil swelling causes an increase in the plasticity limit, this is due to the replacement of the fine particles by the larger particles [7, 9]. However, some authors have shown a decrease in the plastic limit, when the material is treated with a mixture of lime-pozzolana with a high content of lime (>10\% lime) [9].

\section{Effect of the cement on the plastic index}

The variation of the plasticity index based on the percentage of cement is shown in Figure 2. It shows a decrease in the plasticity index when the cement content increases. This means an improvement in the behavior of the plastic material. The same trend was observed in $[5,31]$. 


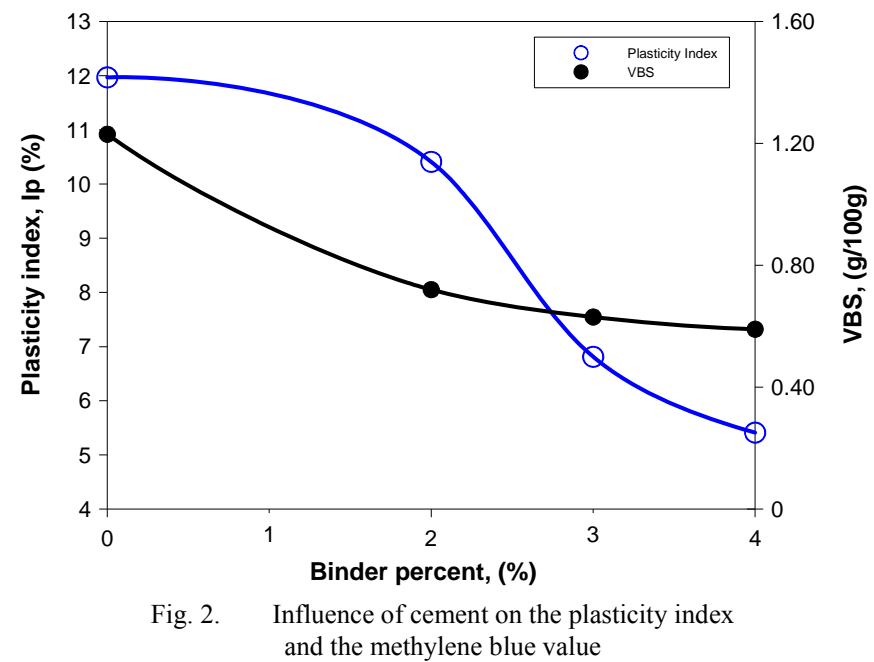

\section{Effect of the cement on the methylene blue value}

The Methylene blue test [18], identifies the reactivity of the clay fraction $(<2$ microns) present in a material by measuring the ability of the fine particles to absorb methylene blue. After several attempts to blue on samples treated and untreated cement, there has been a significant change in measurements of blue with increasing percentage of cement. The results shown in Figure 2 show a decrease in the blue value from 1.23 to 0.59 $(\mathrm{g} / 100 \mathrm{~g})$ with the increase of the cement content. This highlights the insensitivity of the material after water treatment.

\section{E. Effect of the cement on the classification of the material}

The different results of tests on Atterberg limits, natural material and treated are shown in the diagram of plasticity of Casagrande (Figure 3). According to this diagram, the untreated material is associated with the class of so-called low plasticity clay loam (CL) materials. After adding different percentages of cement, the material exhibits a change of class and is positioned below the A-line. Therefore, soil class of CL turned into a soil class of CL-ML (silt of low plasticity). These class changes are assigned by the flocculation of the material when the cement stabilized. In addition, changes in plasticity characteristics of the treated material, allow therefore its use in roadworks (subgrade). Even after treatment we found that the material remains in the same family group $\left(\mathrm{A}_{1}\right)$ according to [12]. Despite the considerable decrease in the blue value and the plasticity index, similar results were found in [9].

\section{F. Effect of the cement on the properties of optimum Proctor}

In our case, the material to be treated contains a large proportion of fine particles $(56.80 \%)$ and an organic matter content of about $1.35 \%$. The selected additive is artificial Portland Cement (CEM I). Treatment with cement according to [17] is made. Doses vary from 2 to $4 \%$ by weight of dry soil. The soil cement mixture is homogenized for about $15 \mathrm{~min}$. However, we proceed in the same way to the Standard Proctor test in CBR mold. The results before and after treatment are shown in Figure 4. It is found that the dry density significantly increases the dry side of the optimum and remains substantially equal to the wet side of the optimum for different percentages of cement imposed. This leads us to say that the maximum dry density increases with increase in the percentage of cement in a CBR mold. In contrast, the corresponding optimal water content decreases as the addition of cement is important.

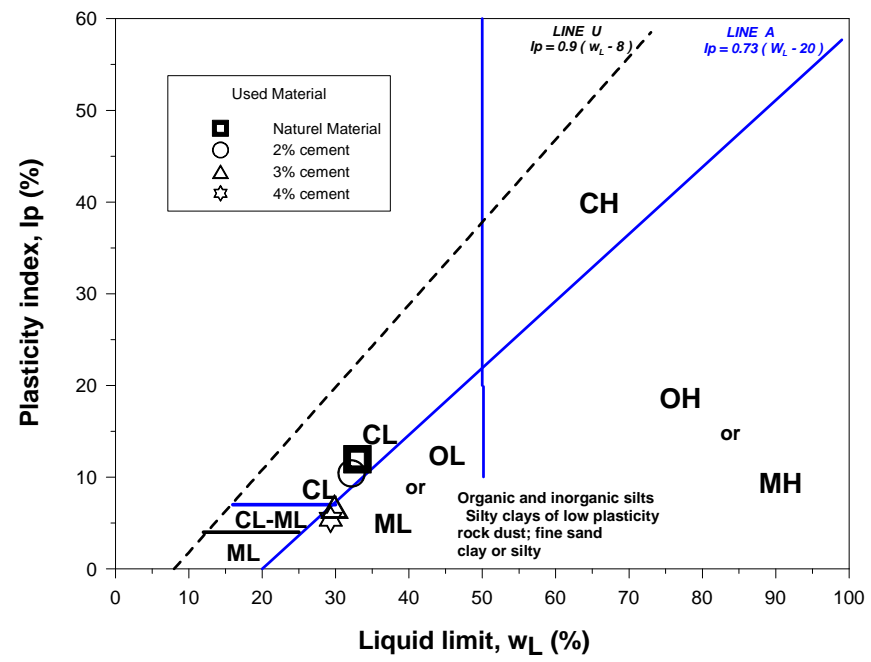

Fig. 3. Diagram of plasticity of Casagrande : - case of the material studied

We can say that the behavior during the compaction of soil treated with hydraulic binder is slightly modified compared to treatment with lime. It should be noted that the optimum water content is shifted to the higher water content and dry density is equal to or slightly lower, the optimum moisture content is decreased and dry density is increased when treating a ground hydraulic binder. The addition of a binder in the soil causes a change in its water content. This effect is more significant with the lime than with hydraulic binders. It should also be noted that, for a given water content of the wet side of the optimum resistance measured using the CBR test are lower for samples that are subjected to high energy compaction (Case of modified Proctor).

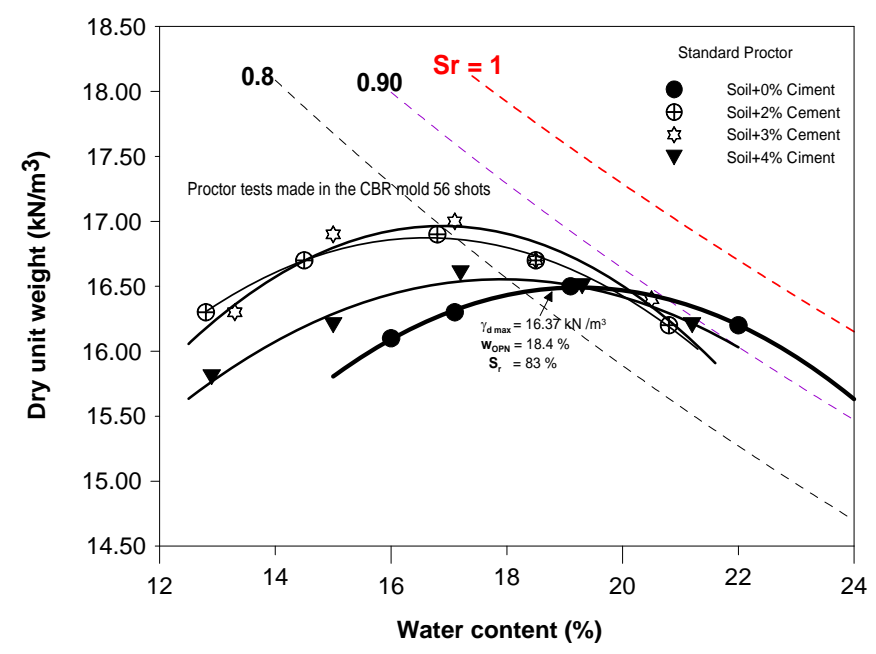

Fig. 4. Influence of cemnt on the optimal properties 


\section{CONCLUSIONS}

The objective of the study was to characterize a material to be used in road construction, relying on a process of recovery, taking into account treatment with reasonable dosages of cement with normal compaction. Results allow the consideration of the use of the material as subgrade in a body floor. Improving material properties by a significant energy compaction is not an effective solution as it required an increase of the maximum dry density of $1.1 \mathrm{kN} / \mathrm{m}^{3}$ which is not consistently seen in the measurement tolerance specified by the standards. It is therefore best to follow a different path, aiming to improve the geotechnical properties of soils by adding a chemical compound such as cement strength class 32.5 (CEM I) and proceed to a standard compaction (OPN). The amount of treatment product is expected to be $3 \%$ cement and it is expected to reduce the water content due to hydrations phenomena and improve the dry density. According to the results of this study, the cement can be a good treatment for a class $\mathrm{A}_{1 \mathrm{~h}}$ material. The pattern of results show a slight reduction in the liquid limit, an increase of the plastic limit, and therefore, a reduction of the plasticity index. As shown, when applying a certain amount of cement to the soil it passes brutally from a plastic state to the crumbly state. The analysis reveals a difference of the soil's behavior in regards of the way of treatment (mechanical or chemical). The major difference between the two types of treatment relates to the size of the mold, which on site, may result to less roller passes and thus avoidance of over-compaction.

\section{REFERENCES}

[1] A. L. Bell, "The development and importance of construction technique in deep vibratory ground improvement" in Ground and Soil Improvement, Thomas Telford, pp. 103-111, London, United Kingdom, 2004

[2] B. C. Slocombe, A. L. BELL, J. I. BAEZ, "The densification of granular soils using vibro methods", Geotechnique, Vol. 50, No. 6, pp. 715-725, 2000

[3] E. E. Alonso, A. Gens, A. Lloret, "Precompression design for secondary settlement reduction", Geotechnique, Vol. 50, No. 6, pp. 645-656, 2000

[4] F. G. Bell, Engineering treatment of soils, Chapman and Hall, London, 1993

[5] C. O Okagbue, J. A. Yakubu, "Limestone ash waste as a substitute for lime in soil improvement for engineering construction", Bulletin of Engineering Geology and Environment, Vol. 58, No. 2, pp. 107-113, 2000

[6] A. A. Al-Rawas, A. W. Hago, H. Al-Sarmi, "Effect of lime, cement and sarooj (artificial pozzolan) on the swelling potential of an expansive soil from Oman", Building and Environment, Vol. 40, No. 5, pp. 681-687, 2005

[7] R. K. Goswami, B. Singh, "Influence of fly ash and lime on plasticity characteristics of residual lateritic soil", Ground Improvement, Vol. 9, No. 4, pp. 175-182, 2005

[8] S. Kolias, V. Kasselouri-Rigopoulou, A. Karahalios, "Stabilisation of clayey soils with high calcium fly ash and cement", Cement and Concrete Composites, Vol. 27, No. 2, pp. 301-313, 2005

[9] K. Harichache, M. Gherici, S. Kenai, "Effet de la chaux et de la pouzzolane naturelle sur le comportement de plasticité des sols argileux", 1er Congrès international - DCDD2011- Tébessa, 17-19 2011
[10] J. B. Croft, "The Structure of soils stabilized with cementitious agents", Engineering Geology, Vol. 2, No. 2, pp. 63-80, 1967

[11] J. D. Nelson, D. J. Miller, Expansive soils: problems and practice in foundation and pavement engineering, John Wiley and Sons, New York, 1992

[12] Guide Technique pour la réalisation des remblais et des couches de forme, fascicule I, principes généraux, 2000

[13] AFNOR NF-P11-300, Exécution des terrassements, Classification des matériaux utilisables dans la construction des remblais et couche de forme, 1992

[14] AFNOR NF P 94-68, Sols: reconnaissance et essais, Mesure de la capacité d'adsorption de bleu de méthylène d'un sol-Détermination de la valeur de bleu de méthylène d'un sol par l'essai à la tâche, 1998

[15] AFNOR NF P 94-51, Sols: reconnaissance et essais, Détermination des limites d'Atterberg - Limite de liquidité à la coupelle-limite de plasticité au rouleau, 1993

[16] AFNOR NF P 94-50, Sols: reconnaissance et essais, Détermination de la teneur en eau pondrale des matériaux-méthode par étuvage, 1995

[17] AFNOR NF P 94-100, Sols: reconnaissance et essais, Matériaux traités à la chaux et/ou aux liants hydrauliques-Essai d'évaluation de l'aptitude d'un sol au traitement, 1999

[18] D. T. Davidson, R. L. Handy, "Lime and lime applications" in Highway Engineering Handboo, pp. 23-98, M.C Graw Hill, New York, 1960.

[19] O. L. Lund, W. J. Ramsey, "Experimental lime stabilization in Nebraska", Highway Research Board Bulletin, Vol. 231, pp. 24-59, 1965

[20] H. Newbauer, M. Thompson,. Stabilization properties of uncured limetreated fined-grained soils. Highway Research Record, Vol. 381, pp. 20 26, 1972

[21] J. Manasseh, A. I. Olufemi, "Effect of lime on some geotechnical properties of Igumale shale", Electronic Journal of Geotechnical Engineering, 13A, pp. 1-12, 2008

[22] D. Turker, E. Cokca, "Effects of addition of fly ash on swell potential of an expansive soil", in Expansive soils-Recent advances in characterization and treatment, pp. 453-463, Taylor \& Francis, London, UK, 2006

[23] N. Degirmenci, A. Okucu, A. Turabi, "Application of phosphogypsum in soil stabilization", Building and Environment, Vol. 42, No. 9, pp. 3393-3398, 2007

[24] A. Reyes, M. Pando, "Evaluation of CFBC fly ash for improvement of soft clays", World of Coal Ash (WOCA), Covington, Kentucky, USA, May 7-10, 2007

[25] M. R. Thompson, "Lime-treated soils for pavement construction", Journal Highway Division, Vol. 94, No. 2, pp. 59-67, 1965

[26] R. N. Yong, V. R. Ouhadi, "Experimental study on instability of bases on natural and lime/cement stabilized clayey soils", Applied Clay Science, Vol. 35, No. 3-4, pp. 238-249, 2007

[27] N. O. Attoh-Okine, "Lime treatment of laterite soils and gravelsrevisited", Construction and Building Materials, Vol 9, No. 5, pp. 283287, 1995

[28] F. G. Bell, "Lime stabilization of clay minerals and soils", Engineering Geology, Vol. 42, No. 4, pp. 223-237, 1996

[29] A. S. Muntohar, G. Hantoro, "Influence of rice husk ash and lime on engineering properties of a clayey subgrade", Electronic Journal of Geotechnical Engineering, Vol. 5A, pp. 1-9, 2000

[30] E. A. Basha, R. Hashim, A. S. Muntohar, "Effect of the cement-rice husk ash on the plasticity and compaction of soil", Electronic Journal of Geotechnical Engineering, Vol. 8A, pp. 1-8, 2003

[31] R. L. Parsons., E. Kneebone, "Field performance of fly ash stabilized subgrade”, Ground Improvement, Vol. 9, No. 1, pp. 33-38, 2005 